九州大学学術情報リポジトリ

Kyushu University Institutional Repository

\title{
Alternative Magmatic Processes of Continental Growth in an Island Arc
}

Yanagi, Takeru

Faculty of Science, Kyushu University

https://doi.org/10.5109/1546075

出版情報：九州大學理學部紀要：Series D, Geology. 24 (3)，pp.189-206，1981-01-20. Faculty of Science, Kyushu University バージョン：

権利関係 : 
Mem. Fac. Sci., Kyushu Univ., Ser. D, Geol., Vol. XXIV, No. 3, pp. 189-206, text-figs. 1-9, January 20, 1981

\title{
Alternative Magmatic Processes of Continental Growth in an Island Arc
}

\author{
Takeru YANAGI
}

\begin{abstract}
Physiographic configurations of island arcs indicate that the growth of a volcanic arc and an outer arc is alternative. The Miocene igneous activities in Japan indicate that the emplacement of granitic plutons occurs alternatively in the volcanic arc or the outer arc. The volcanic arc is recorded geologically as a belt of an intimate association of volcanic rocks and subsequent granitic plutons, and the outer arc as a belt of granitic plutons with no or few contemporaneous volcanic rocks.

To explain these relationships, two alternative fractionation models proposed by YANAGI (1975) were developed under possible geophysical conditions under the island arc. The volcanic arc may owe its growth to batch fractionation of a series of parental magmas. Thick overlying crust and a sufficient rate of magma supply to the chamber are indispensable conditions to keep the batch fractionation working. In case the conditions are not fulfilled, magmas may migrate horizontally along the crust-mantle boundary surface and then accumulate behind the aseismic front, resulting in the formation of the outer arc behind the aseismic front. These two alternative magmatic processes give a good explanation to the geological observations.
\end{abstract}

\section{Introduction}

An arc-trench system is a site of intense igneous activities and tectonic movements. The igneous activities there have two modes of occurrence. One is volcanism which produces a large amount of volcanics on a volcanic arc. Rocks of the calc-alkali series are predominated. The other is the emplacement of granitic plutons. The origin of both the calc-alkali volcanic rocks and the granitic plutons is a fundamental petrological problem in relation to the crustal evolution of the arc-trench system.

The site of emplacement of granitic plutons is an important geological problem as well as their origin. The volcanism occurs on the continental side in the arctrench system. As often observed in eroded arcs, such volcanism was followed by the emplacement of granitic plutons. Besides these, granitic plutons sometimes occur without any contemporaneous volcanic rock in much oceanward forearc area in accreted sedimentary bodies, as seen in the Ryukyu arc. Therefore any hypothesis concerning the origin of the granitic plutons should deal with these two cases of emplacement.

YANAGI (1975), and YANAGI and IsHIZAKA (1978) have attempted to connect

Manuscript received October 3, 1980. 
the genesis of continental crust with those of the granitic plutons and the calcalkali volcanic rocks. Since the proposed hypothesis has been successfully warranted by $\mathrm{K}, \mathrm{Rb}$, and $\mathrm{Sr}$ geochemistry, it should be also checked by another lines of evidence. For geological verification of the hypothesis, it is necessary to designated the site of the granite emplacement in the arc-trench system and to clarify what kind of geological relationship exist between the genesis of the calc-alkali volcanic rocks and that of the granitic plutons. To do these, geological and geophysical observations which are related to the problems will be presented first and then the models in the hypothesis will be improved to meet the geophysical constraints of the mantle and the crust of the arc-trench system.

\section{Configuration of an arc-trench system}

A ridge of an arc-trench system generally has double configuration. One is a volcanic arc which represents in general the inner margin of the ridge (on the continental side). The other is an outer $\operatorname{arc}^{11}$ which represents the outer margin of the ridge (on the oceanic side). This configuration does not depend on the degree of evolution of the island arc. The Tonga arc-trench system, which exemplifies an immature stage with very thin crust, has the volcanic arc represented by the Tafua island and others, and the outer arc on which the Vavau and Eua islands lie. In the Kurile arc-trench system the volcanic arc is represented by fairly large volcanic islands such as Kunashir, Iturup, Urup and Paramashir, but the outer arc, represented by the Nemuro peninsula of Hokkaido and its eastward extension, is at a germinating stage and lies below the sea level for the most part. In the Ryukyu arc-trench system major islands such as Tanega-shima, Yaku-shima, Amami-oshima, Okinawa, Miyako and Ishigaki lie on the outer arc. At the distance of about $50 \mathrm{~km}$ behind this outer arc, a line of very small volcanic islets represents the volcanic arc. In Northeast Japan the outer arc is represented by the Kitakami and Abukuma mountains and the volcanic arc by the Nasu active volcanic zone. There is a topographic depression between the outer arc and the volcanic arc, but it is not submerged under the sea.

It is evident from the examples that the degree of development of the outer arc in comparison with the volcanic arc is variable. To illustrate this more clearly, areal proportions of islands lying on each of the volcanic arc and the outer arc are shown in Fig. 1 for representative two cases of the Kurile and Ryukyu arc-trench systems. The surface extension more than 95 percent of the total area of islands of the Kurile arc-trench system comes from the volcanic arc, and islands lying on the outer arc give only 5 percent. The islands lying on the outer arc of the Ryukyu arc-trench system have an extension over 90 percent of the total area. The highly contrasted configurations of these two arctrench systems suggest that the development of the outer arc and the volcanic arc is alternative. In extreme cases, the island arc becomes single, being represented by only one of these two arcs.

1) The outer arc in this paper may correspond with the frontal are in KARIG and SHARMAN (1975). 


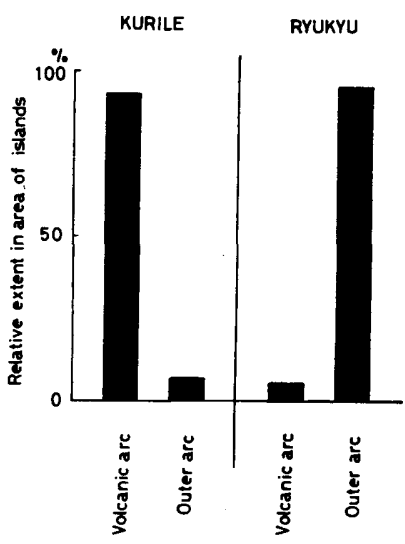

Fig. 1. Comparison between the Kurile and the Ryukyu arc-trench system on the areal proportion of islands lying on the volcanic arc and the outer arc.

\section{Uplifting of the outer arc}

Many islands lying on the outer arc have a set of multiple terraces along the coastline. It is a record of successive or intermittent uplift. Multiple terraces were formed along the Pacific coast of Northeast Japan (OTA and NARUSE, 1977). The hight of the late Pleistocene terrace range from 40 to $100 \mathrm{~m}$ in the Kitakami mountains and from 40 to $60 \mathrm{~m}$ in the Abukuma mountains (OTA and NARUSE, 1977; OTA and YoshiKaWA, 1978). The peneplane of the Abukuma mountains is tilted to west and some rivers running through the eastern part of the mountains are rejuvenated (KANO et al., 1973). Geological units constituting both the Kitakami and Abukuma mountains are much older than those of the volcanic zone. They are Paleozoic to Mesozoic formations and plutonic rocks. The geology of the volcanic zone behind the outer arc consists, for the most part, of Neogene clastic sediments plus volcanics and recent volcanic rocks.

Recent limestones cut by NNW-SSE parallel faults form a set of terraces on the Miyako island, Ryukyu. These terraces become higher toward the Ryukyu trench (KoNISHI, 1967). Radiometric dating of reef corals on the Kikai and Okinoerabu islands shows that a rate of uplifting is higher in an island closer to the Ryukyu trench (KoNISHI et al., 1970). Geological units constituting most parts of the islands lying on the outer arc are also older than those of the volcanic islands. Ages of these geological units range from late Paleozoic up to Miocene time, while recent volcanics cover the volcanic islands (KoNisHI, 1965).

The outer arc of the Tonga arc-trench system is mostly below the sea water. Seismic reflection profiles across the outer arc indicate that sediments deposited on the ridge show rearward tilting and they are cut by some parallel faults at the outer margin of the ridge (KARIG, 1970). These lines of evidence indicate that the outer arc of active arc-trench system is successively rising and rotating away from the ocean.

\section{Volcanic arc and aseismic front}

Northeast Japan is a well-studied example of active island arcs. There occur 
intense volcanism and earthquakes. The distribution of volcanoes in Northeast Japan (Fig. 2) is sharply demarcated by the volcanic front (SUGIMURA et al., 1963). The volcanic activity occurs in a zone of about $200 \mathrm{~km}$ wide. The volcanic rocks show the maximum volume immediately behind the volcanic front. Going from the volcanic front towards the continent, the volume of the volcanics decreases steeply and then becomes zero at a distance of about $200 \mathrm{~km}$ (SUGIMURA et al.,

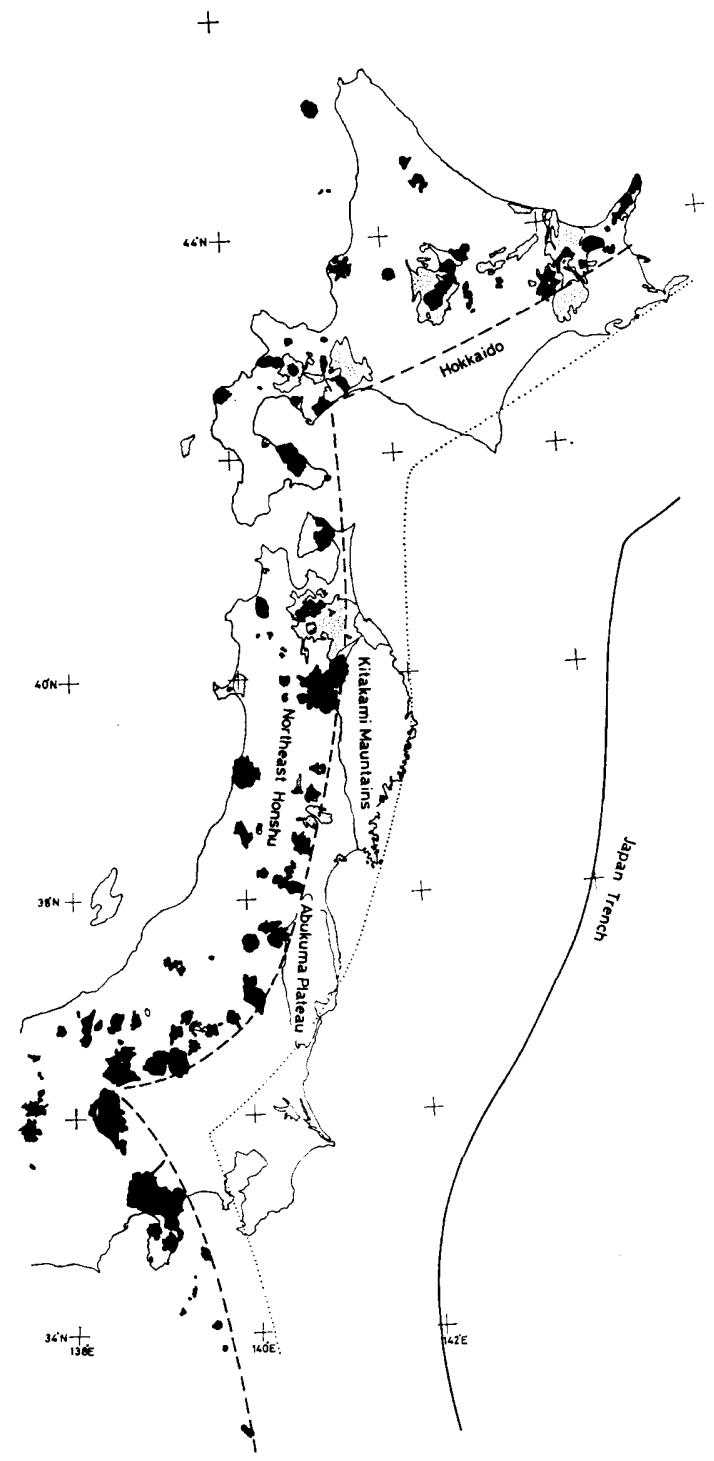

Fig. 2. Distribution of recent volcanic rocks in Northeast Japan (modified from the Geological map of Japan $1: 1,000,000$ (HIRoKaWA et al., 1978)). Solid area: basic to intermediate volcanics, Dotted area: acid volcanics, Broken line: volcanic front, Dotted line: aseismic front, Solid line: Japan trench. 
1963). The intense volcanic activity results in the formation of the prominent ridge behind the volcanic front. Magma chamber is suggested to exist under the volcanic zone from a fact that seismic waves from shallow earthquakes lying along the trench are much attenuated when they are transmitted across the volcanic front (IKAMI, 1975).

The spatial relationship between the volcanic front and the aseismic front is shown in Fig. 2. The aseismic front has been proposed by YosHII (1975) from a fact that the occurrence of earthquakes at depths of $40-60 \mathrm{~km}$ is confined within a zone between this front and the trench. The aseismic front runs along the Pacific coastline of the outer arc of Northeast Japan, and in parallel to the volcanic front. The distance between the volcanic front and the aseismic front is about $75 \mathrm{~km}$, although it is narrowed to about $40 \mathrm{~km}$ in the north of the Izu-

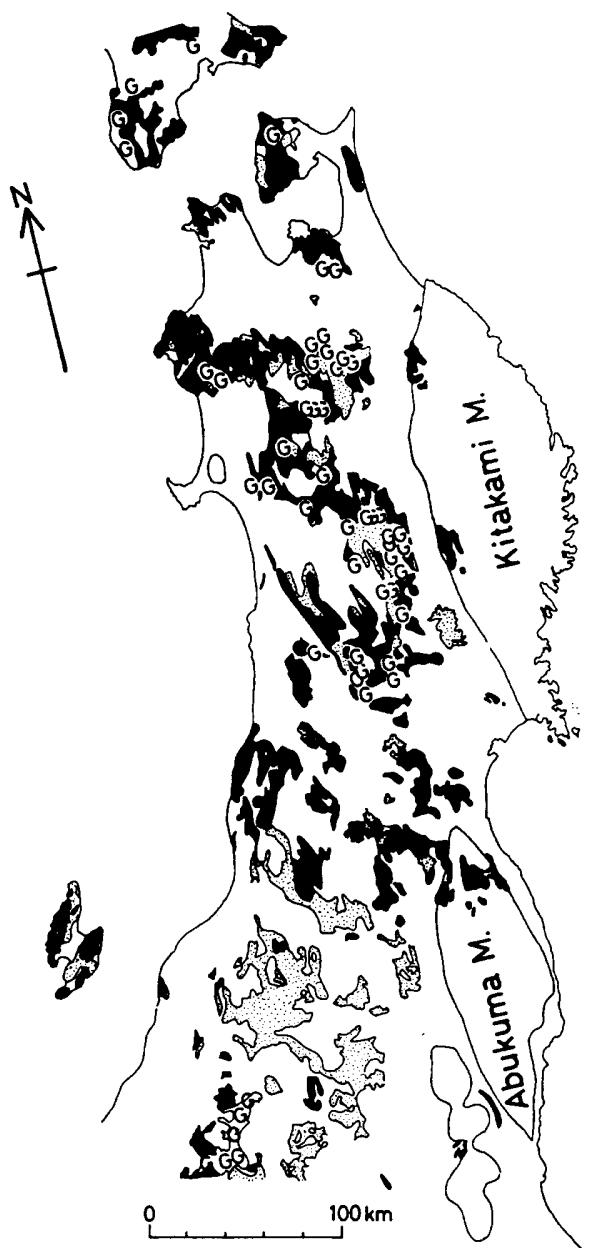

Fig. 3. Distribution of Miocene volcanic rocks and granitic plutons in Northeast Japan (modified from the Geological map of Japan, $1: 1,000,000$ (HIrokawa et al., 1978)). Solid area: basic to intermediate volcanics, Dotted area: acid volcanics, G: granitic plutons. 
Mariana arc-trench system. The northward extension of this aseismic front is bended to northeast at the south of Hokkaido and then runs parallel to the volcanic front of the Kurile arc. In the Kurile arc it goes along the outer margin of the outer arc. The southward extension is connected to that of the Izu-Mariana arc. The outer arc is not distinct physiographically in the north of the IzuMariana arc-trench system, where the distance between the aseismic front and the volcanic front is narrowed.

\section{Volcanism and granite emplacement}

Igneous activities occurred in Northeast Japan and Southwest Japan in the Miocene time. They are good examples to see the relationship between the volcanism and the emplacement of granitic plutons. Styles of the igneous activities are quite different. In Northeast Japan, violent volcanic activity took place everywhere in an elongated depression behind the outer arc (Fig. 3). The volcanic activity commenced in early Miocene and continued until late Miocene (FUJIoKA et al., 1977). The thick volcanic accumulation consists of lava flows and pyroclastics, mostly of andesites and dacites. The rocks are altered by hydrothermal solution related to the volcanism. The pyroclastics are abundant, indicating violent

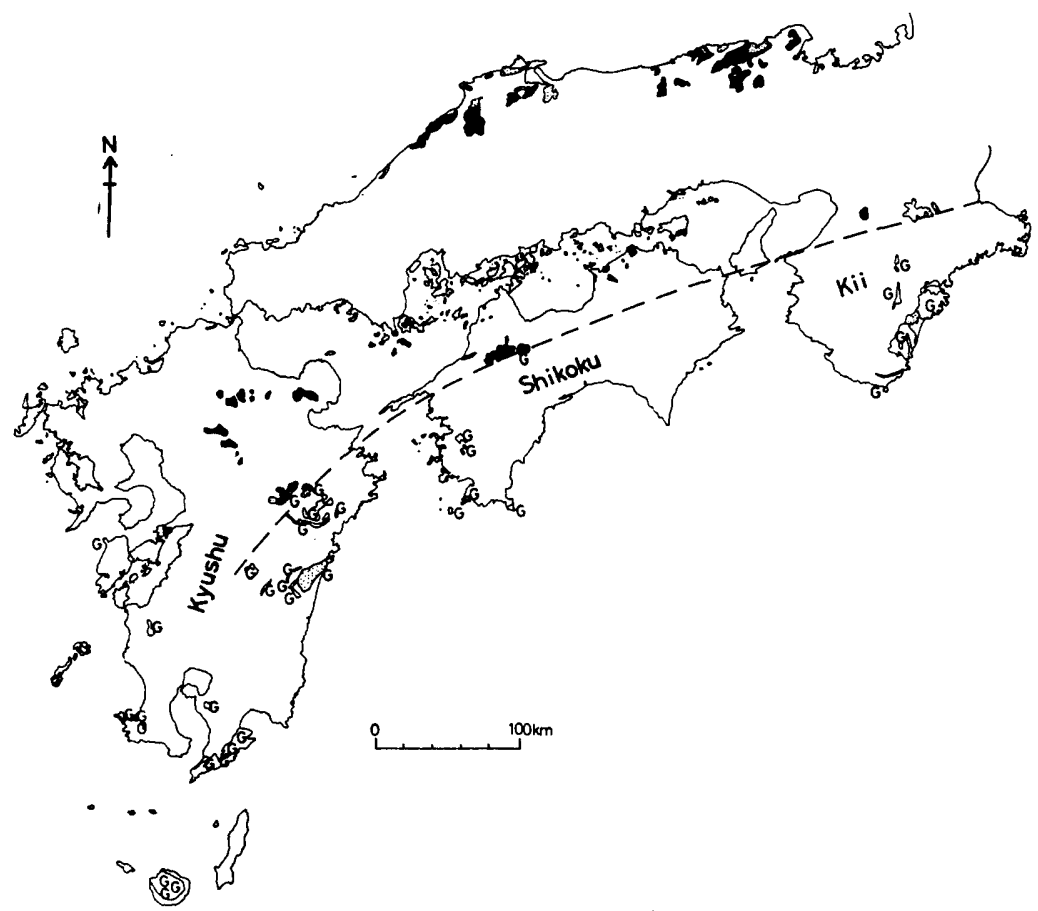

Fig. 4. Distribution of Miocene volcanic rocks and granitic plutons in Southwest Japan (modified from the Geological map of Japan, $1: 1,000,000$ (HIrokawa et al., 1978)). Solid area: basic to intermediate volcanics, Dotted area: acid volcanics, Broken line: the oceanward limit of distribution of basic to intermediate volcanics. 
explosive volcanism. Ore deposits related to the volcanism occur frequently in the volcanic succession. In association with the decline of the volcanic activity, the basin began to uplift to form a mountain range. Non-marine sediments of late Miocene cover the volcanic and marine sedimentary successions. Many small stocks of granitic plutons are distributed sporadically but restrictedly in this region (Fig. 3).

In contrast to the abundant occurrence of volcanic rocks in Northeast Japan, the volcanics in Southwest Japan are so limited and sporadical that the concept of volcanic arc can indefinitely be applied to this region (Fig. 4). The total area of the volcanic outcrops is less than one tenth of that in Northeast Japan. The volcanics occur on the continental side. The Pacific coastal region where Miocene marine sediments were deposited was uplifted during the middle to late Miocene. In the middle Miocene, the emplacement of granitic plutons occurred mostly in an area outside the volcanic zone (Fig. 4). The granitic plutons are rather abundant in contrast to the contemporaneous volcanics. Most of these granitic plutons are not associated with volcanic rocks. They intruded themselves into densely imbricated sedimentary bodies which have tectonic and sedimentary features characteristic of accretionary prism formed at the trench (SAKAI, 1978). The Kumano and Osuzu acid igneous complexes are exceptional cases among these granitic plutons. These complexes consist of granitic plutons and related pyroclastic volcanic rocks (ARAMAKI, 1965; NAKADA, 1978). The oceanward limit of the granite emplacement in land is about $100 \mathrm{~km}$ apart from the volcanic zone. The granitic plutons in the coastal region are distinct and are traced to contemporaneous stocks in the outer arc of the Ryukyu arc-trench system. It should be noted that such granitic plutons in the coastal region often have xenoliths of metamorphic rocks such as gneisses and schists of low $\mathrm{P} / \mathrm{T}$ type. Sillimanite, garnet and cordierite have been reported from these xenoliths (NozAWA and OTA, 1965). Fig. 5 illustrates the difference in the site of granite emplacement between Northeast Japan and Southwest Japan. All the granitic stocks in Northeast Japan occur in the volcanic zone. On the contrary, about 98 percent of the

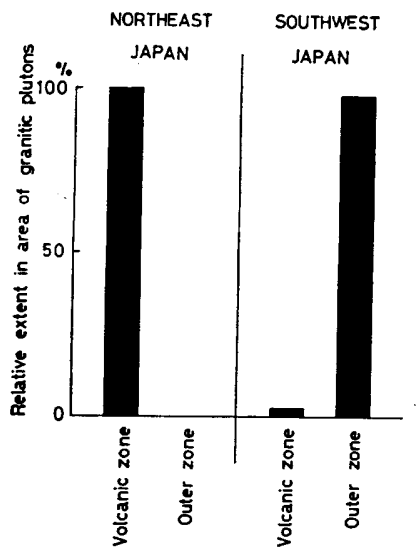

Fig. 5. Comparison between Northeast Japan and Southwest Japan on the areal proportion of Miocene granites' outcrops in the volcanic zone and outside the volcanic zone (outer arc). 
total extent of granite outcrops in Southwest Japan comes from outside of the volcanic zone.

\section{Late Mesozoic igneous activities in Southwest Japan}

Much eroded Mesozoic examples in the Inner Zone of Southwest Japan provide us knowledge of geological relationships among volcanic rocks, granitic plutons and other geological units. The late Mesozoic igneous activities are recorded there as an intimate association of andesitic volcanic rocks, dacitic to rhyolitic pyroclastics and batholithic plutons in a belt measuring about $800 \mathrm{~km}$ in length and about $120 \mathrm{~km}$ in breadth (Fig. 6). This belt is bounded on the south by a zone of metamorphic rocks of a high $\mathrm{P} / \mathrm{T}$ type, which is called the Sanbagawa metamorphic belt. This metamorphic belt makes a pair with that lying along the southern border of the igneous belt (MIYASHIR0, 1961). The latter, which is called the Ryoke metamorphic belt, is of a low $\mathrm{P} / \mathrm{T}$ type. The metamorphic rocks are intimately associated with granitic plutons. The igneous belt and the Sanbagawa metamorphic belt are in fault contact. To the further south, there occur non- or weakly-metamorphosed late Paleozoic to Mesozoic sedimentary formations (Chichibu Terrain). Most of them are imbricated and cleaved.

So far as the available data are concerned, the igneous activities commenced with andesitic volcanism in the Aptian-Albian time (SHIBATA et al., 1978) in the northern half of the igneous belt and continued for a rather long period up to early Tertiary (MURAKAMI, 1974). The granitic plutons in the southern half, however, are suggested to be much older (MURAKAMI, 1974; YAMADA, 1977). Although no critical datum indicating an age of emplacement comes from the southern half, intrusive relationships indicate that granitic plutons associated with the low $\mathrm{P} / \mathrm{T}$ metamorphic rocks in the southern half are older than those cropping out in the northern half. Apart from the southern half, the andesitic volcanism recorded in the Kwanmon Group was followed by thick accumulations of pyroclastics, sometimes with intercalation of lava flows and clastic sediments. These are mostly dacitic to rhyolitic, and often welded. The distribution of these volcanic rocks is very extensive, but is restricted in the northern half of the igneous belt (Fig. 6). The andesitic rocks including those in the Kwanmon Group are subordinate and their distribution is sporadical, being limited in much narrower area of the northern half (Fig. 6). Major granite emplacement in the northern half took place after the pyroclastic volcanism, giving thermal effects to the surrounding volcanic rocks.

Late Mesozoic Southwest Japan with parallel arrangement of constituent geological units is similar in many aspects to the recent arc-trench system. It has the volcanic zone on the continental side and the zone of imbricated and cleaved sedimentary formations on the oceanic side. The southern limit of the distribution of the andesitic rocks is shown in Fig. 6. There are two types of occurrence of granitic plutons. One is those cropping out in the northern half of the igneous belt, which are intimately associated with the volcanic rocks. Such association has already been observed in the Miocene example of Northeast 


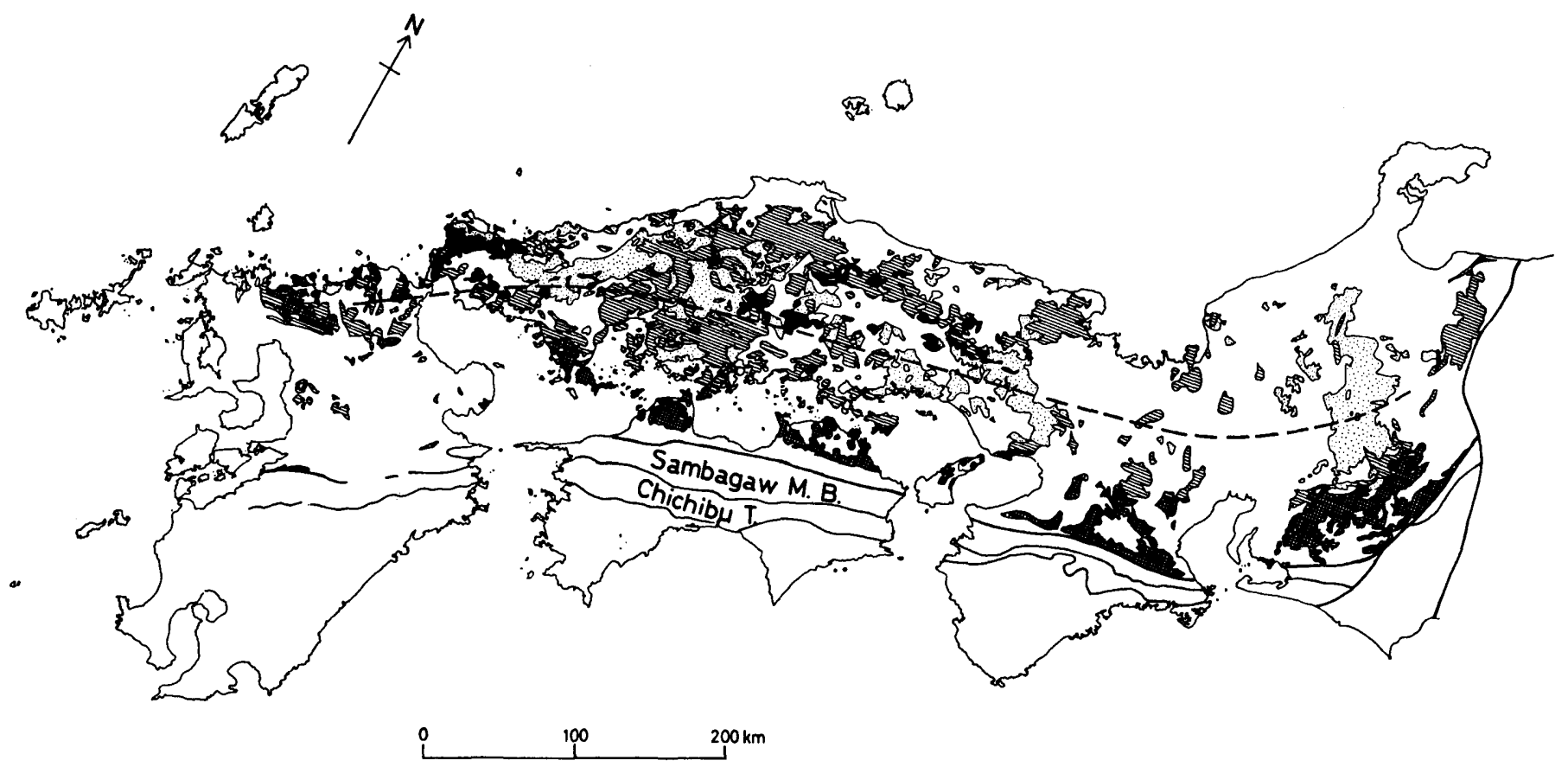

Fig. 6. Distribution of late Mesozoic rocks and granitic plutons in Southwest Japan (modified from the Geological map of Japan, $1: 1,000,000$ (HIrokAWA et al., 1978)). Solid area: basic to intermediate volcanics, Dotted area: acid volcanics, Meshed area: older granitic plutons, Striped area: younger granitic plutons, Broken line: the oceanward limit of distribution of basic to intermediate volcanics. 
Japan. The other is those distributed in the southern half. These are not associated with the volcanic rocks, but intimately associated with the low $\mathrm{P} / \mathrm{T}$ metamorphic rocks. Similar association has already been noted in the Miocene granitic stocks cropping out along the Pacific coastline of Southwest Japan, though the metamorphic rocks appear as xenoliths in the stocks. Thus, the arrangement of the granite-volcanics association in the north and the granitemetamorphics association in the south is a characteristic of the igneous belt. The separation of the southern limit of the granite emplacement from the volcanic zone, especially the zone of andesitic volcanism, is almost constant along the whole extension of the igneous belt. The distribution of the pyroclastic volcanic rocks beyond the andesitic volcanic zone has already been noted in the Miocene example of southwest Japan. The distance between the andesitic volcanic zone and the southern limit of the granite emplacement is about $80 \mathrm{~km}$. This distance is very close to that between the recent volcanic front and the aseismic front in Northeast Japan.

\section{Structural model across the arc-trench system}

Fig. 7 is the structural model proposed by YoshII (1975) across Northeast Japan. Seismically active areas are shown by dots in this figure. The seismic activity is confined within two parts: one is the crust and the other is an inclined seismic zone dipping from near the trench to the mantle under the arc. Shallow earthquakes are concentrated in the area between the outer arc and the trench, where great earthquakes frequently occur. Relatively large earthquakes also occur near the Japan Sea coast and small ones under the volcanic zone. It is worthwhile to note that earthquakes occur scarcely in the outer arc (FUJII and KURITA, 1978). This contrasts with high seismic activity in the neighboring zone to the east.

Active island arcs have an anormalous mantle structure (UTSU, 1968 and 1971). On the basis of analyses of the seismic area and the travel times of seismic

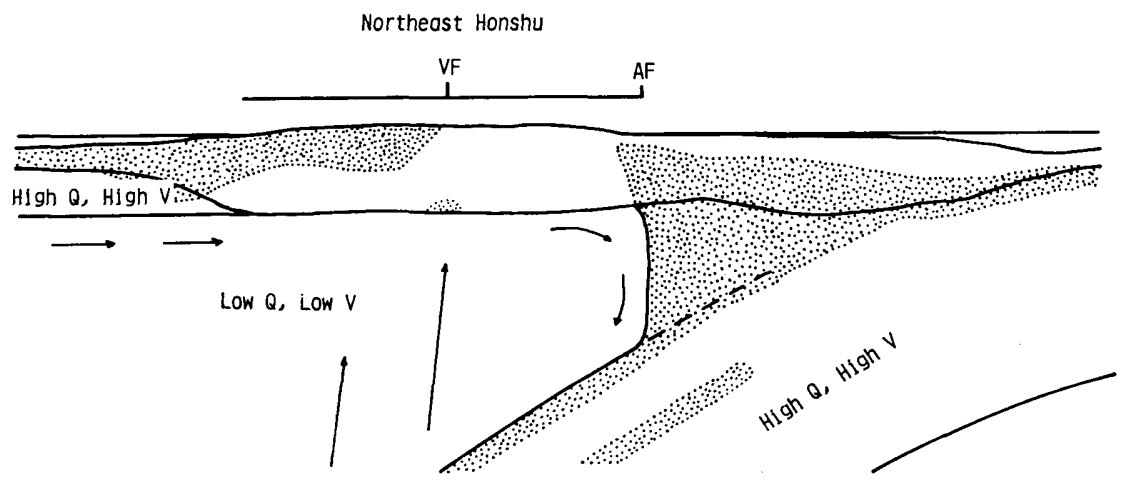

Fig. 7. Structural model across Northeast Japan (YoshII, 1972 and 1975) with hypothetical convectional movement (WADACHI and TAKAHASHI, 1974) in the low Q, low V mantle. Dotted areas represent seismologically active areas and arrows indicate the convectional movement. 
waves, UTSU (1971) proposed a structural model, in that the high Q, high V zone of about $100 \mathrm{~km}$ wide dips from near the trench to the mantle under the island arc and the low $\mathrm{Q}$, low $\mathrm{V}$ mantle lies on this inclined zone. This model has now been modified as shown in Fig. 7 by the study of gravity anomalies and the detailed analyses of data obtained from explosive earthquakes (YosHII, 1972 and 1975). In this model, the low $\mathrm{Q}$, low $\mathrm{V}$ mantle underlies immediately below the crust of the arc, and its oceanward edge reaches under the coastline of the outer arc. The oceanward edge is found to coincide with the aseismic front (SUZUKI, 1975; Research Group for Explosion Seismology, 1977). Pn velocity change abruptly across the aseismic front. It is low at about $7.5-7.7 \mathrm{~km} / \mathrm{sec}$ inside the aseismic front and high at about $8.1 \mathrm{~km} / \mathrm{sec}$ outside the aseismic front (Suzukr, 1976; Research Group for Explosion Seismology, 1977). This model is reliable, because the site determination of earthquakes is much improved, especially for those occurred near the trench. Low velocity of $\mathrm{S}$ wave at about $4.2 \mathrm{~km} / \mathrm{sec}$ has been reported from the low Q, low V mantle (KANAMORI and ABE, 1968). Partial melting (KANAMORI, 1968 and 1970; ABE and KANAMORI, 1970) and the existence of magma pockets (SHIMOZURU, 1963; AKI and KANIMURA, 1963; TAKEUCHI et al., 1968) in this mantle have been repeatedly suggested to provide a favourable explanation for the seismological observations of this mantle since SHIMozuRU (1963). High heat flow behind the volcanic front is a remarkable geophysical characteristic. HASEBE et al. (1970) have noted that up-welling mantle convection is required in the anormalous mantle to give a satisfactory explanation of high heat flow in the area behind the volcanic front. For the convenience of later discussions, the flow model in the low $\mathrm{Q}$, low $\mathrm{V}$ mantle suggested by WADACHI and TAKAHASHI (1974) is also indicated in Fig. 7 by arrows.

\section{Fractionation models}

Two alternative fractionation models for the continental growth were proposed by YANAGI (1975): One is batch fractionation and the other is equilibrium incipient melting or equilibrium ultimate crystallization. YANAGI (1975), and YANAGI and IsHIZAKA (1978) have already discussed on the petrochemical characters of the parental magma. The important point is that the parental magmas are supposed to have the $\mathrm{Rb} / \mathrm{Sr}$ ratios clustering at about 0.018 , which is equal to the mean value for oceanic ridge basalts. Most basalts and andesites from island arcs have $\mathrm{Rb} / \mathrm{Sr}$ ratios equal to or greater than this value. The volcanic rocks with $\mathrm{Rb} / \mathrm{Sr}$ ratios less than this value occur very infrequently. It has already been shown that the batch fractionation can produce a liquid with a $\mathrm{Rb} / \mathrm{Sr}$ ratio equal to the average value of the continental crust. The same has also been said for the ultimate crystallization, when the last few percent liquid coexist in equilibrium with the cumulate. Such liquids separated from the fractionation system or from the cumulate become granitic with the successive fractionation in association with upward migration.

Fig. 8 illustrates the process of batch fractionation. It was originally prepared to explain the geochemical characteristics of the Myoko volcanic rocks 


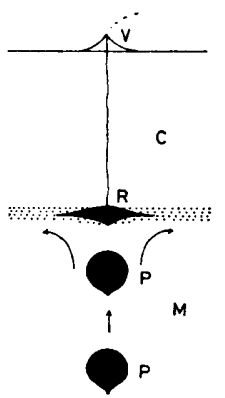

Fig. 8. Schematic illustration of a magma chamber (R) near the base of crust and a volcano (V) lying on the crust (C). The parental magma (P) rising in the mantle (M) is repeatedly added to the chamber. Cumulate (dotted) is removed by the divergent movement (arrows) in the mantle.

(YANAGI and IshIZAKa, 1978). $\mathrm{R}$ is a magma chamber in which crystallization continues and to which the parental magma is repeatedly added. $\mathrm{V}$ is a volcano lying on the crust (C), which is connected by a vent with the chamber. $P$ is the parental magma successively ascending in the mantle (M). The cumulate (dots) formed in the chamber is removed by divergent movement (arrows) of the mantle. Under these conditions the magma in the chamber evolves in chemistry with ascending steps. Being associated with this evolution, the cumulate in the chamber also evolves and the average composition of the cumulate formed during one chemical step eventually becomes equal to that of the parental magma. Under this condition, the variation in chemistry of the magma in the chamber gets a stationary state. The residual magma in each chemical step under the stationary state is estimated to be equal in $\mathrm{Rb} / \mathrm{Sr}$ and $\mathrm{K} / \mathrm{Rb}$ ratios to the average values of the continental crust, as has been confirmed by the analyses of the Myoko volcanic rocks.

In addition to the above points, the indispensable condition for maintaining the batch fractionation stably is the heat balance in the chamber. The loss of heat from the chamber during the crystallization should be recovered by the supply of the parental magma. If at a given site the influx of heat to the chamber by the supply of the parental magma is inferior to the loss of heat during the crystallization, the chamber may be withered away and then ceased to exist. The batch fractionation could not be maintained. The depth at which the heat balance can be realized depends on the rate of magma supply. It increases with the decreasing rate of the supply. This is very important for the following discussions. The process of equilibrium crystallization will be shown later.

\section{Sites of continental growth}

Many authors depict the parental magma coming up in the mantle under the volcanic zone. Similarly I also assume in the structural and flow models of Fig. 7 that the parental magma ascends successively to the top of the mantle under the volcanic zone. This may be in harmoney with the low $Q$ values of the mantle under the volcanic zone. Magma density in the mantle and the velocity of ascent are the major concern for the operation of the batch fractionation. These two give a rate of supply of the parental magma, which, in turn, give the depth at which the supply of heat is equal to the loss of heat to the surface. This 
depth will be refered to as the depth of heat balance. If the rate of supply of the parental magma is so slow that the depth of heat balance is in the mantle, the magma may continue to go up gravitationary and also be carried up by the upward flow of the mantle beyond this critical depth. The batch fractionation could not operate, because the rate of crystallization becomes superior to the rate of the magma supply at such site of shallower depths. The supply of the parental magma should be enough to take the heat balance, at least, at the base of the crust, which can sustain the chamber against the moving mantle. Therefore, the conditions which control the operation of batch fractionation are the rate of supply of the parental magma and the thickness of overlying crust.

When these conditions are not fulfilled, the parental magma comes up to the top of the mantle and then migrates horizontally toward the aseismic front (Fig. $9 \mathrm{~A}$ ). During the migration the magma becomes very flat and thin (Fig. $9 \mathrm{~A}$ ), because of a gravitational effect and laminar flow at the top of the mantle. Hence the magma losses rapidly its heat through its extensive surface. Most part of the magma may be crystallized during the migration for a long distance to the aseismic front. Because of the extensive expansion, the residual magma can coexist with the crystalline cumulate at temperatures prevailing in the mantle behind the aseismic front. Equilibrium relation may be realized between the residual magma and the cumulate. The residual magma disseminated in the cumulate is then gravitationally squeezed out from the cumulate, when the mantle material begins to descend behind the aseismic front (Fig. 9 A). Because of successive accumulation of the residual material, the overlying crust is ultimately uplifted to form the outer arc behind the aseismic front. After the accumulation in a sufficient amount, the accumulated material begins to intrude itself with successive fractionation into the outer arc, resulting in the emplacement of granitic plutons. The accumulation of the plastic material may reduce the occurrence of earthquakes in the outer arc. The rate of accumulation is high behind the aseismic front and decreases with the separation from the aseismic front

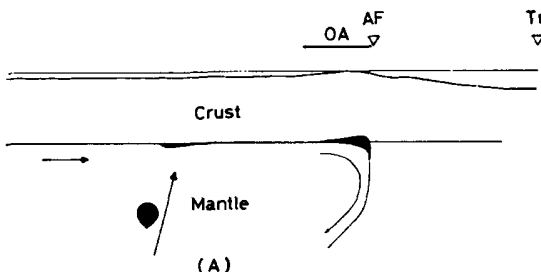

(A)

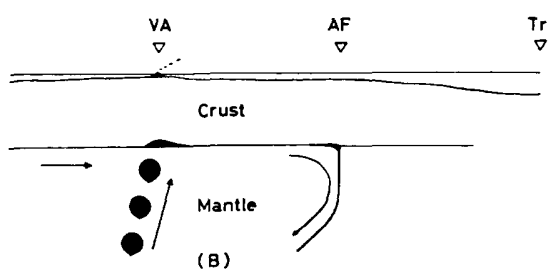

Fig. 9. Schematic illustration of alternative magmatic processes of continental growth. (A) displays the accumulation of residual magma behind the aseismic front and resultant uplift of the outer arc (OA). (B) displays the formation of volcanic are through batch fractionation. 
toward the volcanic zone. Accordingly the crust behind the aseismic front may be rotated away from the ocean. Notably high rates of uplifting recorded along the coastal regions, especially of the island arcs with faint or no volcanism, are well understood in this context. The important facts concerning the outer arc such as its existence, it successive uplifting, its relation in position with the aseismic front, less frequent occurrence of earthquakes and the occurrence of granitic plutons are all related and explained simultaneously by the process of continental growth depicted here (Fig. $9 \mathrm{~A}$ ). So far as this process continues, the outer arc can supply sediments to the trench and also to the associated sedimentary basin behind it.

When both the rate of magma supply and the thickness of crust are enough for the batch fractionation to operate near the base of crust, the magma chamber is formed under the volcanic zone and hence crustic material is produced there (Fig. 9 B). The uplift take place, in this case, in the volcanic zone. The emplacement of granitic plutons may follow the volcanic activity. The abundant occurrence of calc-alkali volcanic rocks, the uplifting of the volcanic zone and the intimate association of the volcanic rocks and granitic plutons are related and explained by the latter process of the continental growth (Fig. $9 \mathrm{~B}$ ).

\section{Alternative relations}

In the first place, an evidence is presented to support the assumption that the operation of batch fractionation depicted here depends on the thickness of crust. YANAGI and IsHIZAKA (1978) have indicated that this fractionation system can transform tholeiitic magmas into calc-alkali magmas. If calc-alkali volcanic rocks in island arcs were originated from this type of fractionation, the occurrence of the calc-alkali volcanic rocks should depend on the thickness of underlying crust and there should be a minimum thickness of crust for the formation of calc-alkali volcanic rocks. MIYASHIRo (1974) has already observed the following facts which well meet the requirements of the model: An abundance of calc-alkali volcanic rocks in island arcs increases with the increasing thickness of underlying crust, and there is the minimum thickness which may be about $12-14 \mathrm{~km}$.

It should be noted that the operation of these two fractionation models is alternative. Which of these models works is determined by both the rate of magma supply and the thickness of the crust. In case the conditions are fulfilled, the volcanic arc may grow through batch fractionation. If the condition are not fulfilled, the outer arc may grow by the accumulation of residual magmas behind the aseismic front. Such alternative growth of the volcanic arc or the outer arc is well exemplified by the Kurile and the Ryukyu arc-trench system, and explicitly displayed in Fig. 1.

The former alternative may be characterized by the intimate association of granitic plutons and a great amount of volcanic rocks in the volcanic zone. This is well exemplified by the Miocene igneous activity in Northeast Japan. The latter alternative may be characterized by the separated occurrence of scanty volcanic rocks in the volcanic zone and granitic plutons in the outer arc. This is 
exemplified by the Miocene igneous activity in Southwest Japan. The alternative emplacement of granitic plutons in the volcanic zone or in the outer arc is shown in Fig. 5.

If the continental growth is continued under the same scheme of the mantle convection for a long geological period, and the rate of supply of the parental magma changes from time to time, the island arc may have features resulted from the integration of the alternative continental growths. Sites of the present volcanic zone and the outer arc in Northeast Japan is almost the same as those of the Miocene time (Figs. 2 and 3). Sugrmura et al. (1963) have shown the variation in volume of volcanic rocks during a period from the Miocene to the present. The volume is much greater in the Miocene than at the present. The equally developed double configuration of Northeast Japan may be an example of the integrated result. The late Mesozoic igneous activities in the Inner Zone of Southwest Japan may be an eroded example, because the igneous activities there continued for a period more than $50 \mathrm{Ma}$. The equal abundance of granitic plutons in the volcanic zone and the outside may be understood in this context.

\section{Concluding remarks}

It can be concluded that the variation in morphological configuration of an island arc comes originally from the difference in the rate of magma supply and the thickness of the crust. These two are the principal factors for determining whether batch fractionation is operative or not. Modifications due to the integration of the alternative continental growths are added to the original variation. There are two alternative types in the original variation: one is an island arc consisting mainly of the volcanic arc and the other is an island arc consisting mainly of the outer arc. Equally developed double arc may be due to the integration. These two alternative types are recorded as quite different geological association of rocks. The intimate association of abundant volcanic rocks and granitic plutons is the expression of the continental growth through batch fractionation. The separated occurrence of scanty volcanics on the continental side and rather abundant granitic plutons on the oceanic side is the manifestation of the continental growth by the accumulation of magmas behind the aseismic front. The intimate association of granitic plutons and low $\mathrm{P} / \mathrm{T}$ metamorphic rocks may also be a characteristic of the latter.

The irregularity of the crust-mantle boundary surface may give a chance to magmas to form a magma chamber between the volcanic zone and the aseismic front. This may result in the emplacement of granitic plutons at intermediate positions between the volcanic zone and the aseismic zone.

The site of the aseismic front may be a reflection of the thermal regime of the upper mantle under the island arc. Whether the batch fractionation is operative or not may give some modification to the thermal regime. When the batch fractionation is operative under the volcanic zone, the parental magma lost its heat at the chamber by thermal conduction, efflux of fluid from the chamber to the overlying crust, and magma eruptions. On the contrary, the loss of heat 
from the parental magma to the surface may take place in the area between the volcanic front and the aseismic front, when the batch fractionation is not operative.

Acknowledgements: I am very grateful to Emeritus Prof. T. Matsumoto, and Profs. M. YAMAgUCHI and M. KANMERA of Kyushu University, and Prof. H. OKADA of Sizuoka University. They read the manuscript and gave me many valuable suggestions which improved the manuscript. The expense of this study was supported in part by a Grant-in-Aid for the Scientific Research (No. 55426) from the Ministry of Education.

\section{References}

Abe, K. and H. Kanamori (1970) : Mantle structure between the Japan Sea as revealed by surface waves. Bull. Earthq. Res. Inst., 48, 1011-1021.

AKI, K. and K. KANimURA (1963) : Love waves from Aleutian shock of March 9, 1957. Bull. Earthq. Res. Inst., 41, 243-259.

Aramakr, S. (1965): Mode of emplacement of acid igneous complex (Kumano acidic rocks). Jour. Geol. Soc. Japan, 71, 525-540. (In Japanese with English abstract).

FUJII, N. and K. KURITA (1978) : Seismic activity and pore pressure across island arcs of Japan. Jour. Phys. Earth, 26, Suppl., 437-446.

HASEBe, K., N. FUJII and S. UedA (1970): Thermal process under island ares. Tectonophys., 10, 335.

HIrokawa, O. (Chief ed.) (1978): Geological map of Japan, 1:1,000,000 (2nd Ed.). Geol. Surv. Japan.

Hujioka, K., A. Ozawa, T. Takayasu and Y. Ikebe (1977): Geology of the Akita district. Quadrangle Series, Scale 1:50,000. Geol. Surv. Japan. (In Japanese with English abstract).

IKAMI, A. (1975) : Attenuation of seismic waves beneath the volcanic front in Japan. Zisin (ii), 28, 61-73. (In Japanese with English abstract).

KANAMORI, H. (1968) : Travel times to Japanese stations from Longshot and their geophysical implications. Bull. Earthq. Res. Inst., 46, 841-859.

KANAMORI, H. (1970): Mantle beneath the Japanese arc. Phys. Earth Planet. Inter., $3,457-483$.

Kano, H. Y. Kuroda, K. Uruno, T. Nureki, S. Kanisawa, T. Maruyama, H. Umemura, H. Mitsukawa, N. Seto, Y. Ohira, S. Sato and N. Issiki (1973) : Geology of the Takanuki district. Quadrangle Series, Scale 1:50,000. Geol. Surv. Japan. (In Japanese with English abstract).

KARIG, D. E. (1970): Ridges and basins of the Tonga-Kermadec island arc system. Jour. Geophys Res., 75, 239-254.

KARIG, D. E. and G. F. Sharman, III (1975): Subduction and accretion in trenches. Geol. Soc. Amer. Bull., 86, 377-389.

Konishi, K. (1965): Geotectonic framework of the Ryukyu Islands (Nansei-shoto). Jour. Geol. Soc. Japan., 71, 437-457. (In Japanese with English abstract).

KoNishi, K. (1967): Rate of vertical displacement and dating of reef limestones in the marginal facies of the Pacific Ocean. Quaternary Res., 6, 207-223. (In Japanese with English abstract).

Konishi, K., S. O. Schlanger and A. ONUma (1970): Neotectonic rates in central Ryukyu islands derived from ${ }^{230} \mathrm{Th}$ coral ages. Marine Geol., 9, 225-240.

MiYashiro, A. (1961) : Evolution of metamorphic belt. Jour. Petrol., 2, 277-331.

MiYAShIRo, A. (1974) : Volcanic rock series in island arcs and active continental margins. Amer. Jour. Sci., 274, 321-335. 
Murakami, N. (1974): Some problems concerning late Mesozoic to early Tertiary igneous activity on the inner side of Southwest Japan. Pacific Geol., 8, 139-151.

NAKAdA, S. (1978): Geology of the Osuzuyama acid rocks, Miyazaki Prefecture, Kyushu, Japan. Jour. Geol. Soc. Japan., 84, 243-256. (In Japanese with English abstract).

NozAWA, T. and R. OTA (1967): Geology of the Uchinoura district. Quadrangle Series, Scale 1:50,000. Geol. Surv. Japan. (In Japanese with English abstract).

OTA, Y. and Y. NARUSE (1977): Marine terraces in the circum-Pacific area with special reference to the crustal movement and sea level change. Kagaku (Science), 47, 281-292. (In Japanese).

OTA, Y. and T. YoshikAWA (1978): Regional characteristics and their geodynamic implications of late Quaternary tectonic movement deduced from deformed former shorelines in Japan. Jour. Phys. Earth, 26, Suppl., 379-389.

Research Group for Explosion Seismology (1977): Regionality of the upper mantle around northeastern Japan as derived from explosion seismic observations and its seismological implications. Tectonophys., 37, 117-130.

SAKar, T. (1978): Geologic structure and stratigraphy of the Shimantogawa Group in the middle reaches of the Gokase river, Miyazaki Prefecture. Sci. Rept. Dept. Geol., Kyushu Univ., 13, (2), 23-38. (In Japanese with English abstract).

Shibata, K., T. Matsumoto, T. Yanagi and R. Hamamoto (1978): Isotopic ages and stratigraphic control of Mesozoic igneous rocks in Japan. In: G. V. CoHEE, M. F. Glaessner and H. D. HedBerg (eds.), Contribution to the geological time scale. Studies in Geology., (6), 143-164, Amer. Assoc. Petrol, Geol.

ShimozUru, D. (1963): Geophysical evidence for suggesting the existence of molten pockets in the Earth's upper mantle. Bull. Volcanol., 26, 181-195.

Sugimura, A., T. Matsuda, K. Chinzei and K. Nakamura (1963): Quantitative distribution of late Cenozoic volcanic materials in Japan. Bull. Volcanol., 26, 125140.

SUzukr, S. (1975) : Determination of earthquake hypocenters in consideration of the lateral variation of velocity in the upper mantle beneath the island arc of Japan. Zisin (ii), 28, 181-199. (In Japanese with English abstract).

SuzuKr, S. (1976) : Lateral variation of $P$ wave velocity in the upper mantle beneath Northeast Japan, as derived from travel time of earthquakes. Zisin (ii), 29, 99-116. (In Japanese with English abstract).

Takeuchi, H., Y. Hamano and Y. HaSegawa (1968): Rayleigh- and Love-wave discrepancy and existence of magma pockets in the upper mantle. Jour. Geophys. Res., 73, 3349-3350.

UTSU, T. (1967): Anomalies in seismic wave velocity and attenuation associated with a deep earthquake zone, 1. Jour. Fac. Sci., Hokkaido Univ. [7], 3, 1-25.

UTSU, T. (1971) : Seismological evidence for anormalous structure of island arcs with special reference to the Japanese region. Rev. Geophys. Space Phys., 9, 839-890.

WADACHI, K. and M. TAKahashi (1974): On the structure of the crust and upper mantle in Japan and its neighborhood (Part 1). Zisin (ii), 27, 42-56. (In Japanese with English abstract).

YAMADA, N. (1977) : Metamorphic and plutonic rocks of the Ryoke belt. In: K. TANAKA and T. NozawA (eds.), Geology and Mineral Recources of Japan, 319-327, Geol. Surv. Japan.

YANAGI, T. (1975): Rubidium-strontium model of formation of the continental crust and the granites at the island arc. Mem. Fac. Sci., Kyushu Univ., [D], 22, (2), $37-98$.

YANAGI, T. and K. IsHIZAKA (1978): Batch fractionation model for the evolution of volcanic rocks in an island arc: An example from central Japan. Earth Planet. Sci., Lett., 40, 252-262.

Yoshir, T. (1972) : Features of the upper mantle around Japan as inferred from gravity 
anomalies. Jour. Phys. Earth, 20, 23-34.

Yoshrr, T. (1975): Proposal of the "Aseismic Front". Zisin (ii), 28, 356-367 (In Japanese). 